\title{
Pengaruh Komunikasi Terapeutik Perawat terhadap Tingkat Kecemasan pada Pasien Pre Operasi
}

\section{Sulastri ${ }^{1}$, Arif Eko Trilianto ${ }^{2}$, Yunely Ermaneti ${ }^{3}$}

1. Rumah Sakit Umum Daerah Dokter Soedarso

Pontianak,

2. Dinas Kesehatan Kab.Probolinggo

3. Universitas Nurul Jadid, Probolinggo

\section{Abstract}

Anxiety is a problem associated with all sorts of foreign procedures that occur when a person feels threatened physical or psychological. Hospitalization and a series of actions procedures before surgery can also cause acute distress and increased anxiety in patients. Range of possible bad could happen that would endanger patients, patients with anxiety showed symtomp irritability, insomnia, restless, listless, crying and not sleeping soundly. The design used is Pre Experiment. Amount of samples 28 respondents. Intake of sampel by using is technics of Quota Sampling. Data collecting use Questionnaire. Processing data using $T$ test (TTest). From the analysis of data obtained 7.111 $T$ and $T$ table calculated with $a=0.05$ is 2.052, 7.111 calculated in order to obtain $T>T$ table 2.052, then the H1 accepted which means there's Influence of Communications of Terapeutik Nurse To Storey Level Dread of Patient of Pre Operate surgical operation room RSUD dr. Abdoer Rahem sub-province of Situbondo. This is seen in patients of pre operation anxiety levels are affected by therapeutic communication. So that each respondent is expected to more actively ask 
anything that is not known to the officer about the anxiety that occurs.

Keywords : Therapeutic Communication, Dread, Pre Operation

\section{Abstrak}

Kecemasan merupakan masalah yang berhubungan dengan segala macam prosedur asing yang terjadi ketika seseorang merasa terancam baik fisik maupun psikologisnya. Hospitalisasi dan rangkaian prosedur tindakan sebelum operasi dilakukan juga dapat menyebabkan distress akut dan meningkatkan kecemasan pada pasien. Berbagai kemungkinan buruk bisa saja terjadi yang akan membahayakan pasien, pasien yang mengalami kecemasan menunjukkan gejela mudah tersinggung, susah tidur, gelisah, lesu, mudah menangis dan tidur tidak nyenyak. Desain yang digunakan adalah Pra Eksperimen. Jumlah sampel 28 responden. Pengambilan sampel dengan menggunakan tehnik Quota Sampling. Pengumpulan data menggunakan Questioner. Pengolahan data menggunakan uji $\mathrm{T}$ (T-Test). Dari hasil analisa data didapatkan $\mathrm{T}$ hitung 7,111 dan $\mathrm{T}$ tabel dengan $\mathrm{a}=0,05$ adalah 2,052, sehingga diperoleh $\mathrm{T}$ hitung 7,111> T tabel 2,052, maka H1 diterima yang artinya ada Pengaruh Komunikasi Terapeutik Perawat Terhadap Tingkat Kecemasan Pasien Pre Operasi Di Ruang Bedah RSUD dr. Abdoer Rahem Kabupaten Situbondo. Hal ini dilihat tingkat kecemasan pasien pre operasi yang dipengaruhi oleh komunikasi terapeutik. Sehingga diharapkan setiap responden lebih aktif menanyakan segala sesuatu yang belum 
Jurnal Keperawatan Profesional (JKP)

Volume 7, Nomor 1 Februari 2019

p-ISSN: 2355-679X; e-ISSN: $\mathbf{x x x x - x x x x}$

https://ejournal.unuja.ac.id/index.php/jkp/index

diketahui kepada petugas mengenai kecemasan yang terjadi.

Kata kunci Komunikasi Terapeutik, Kecemasan, Pre Operasi 
Pendahuluan

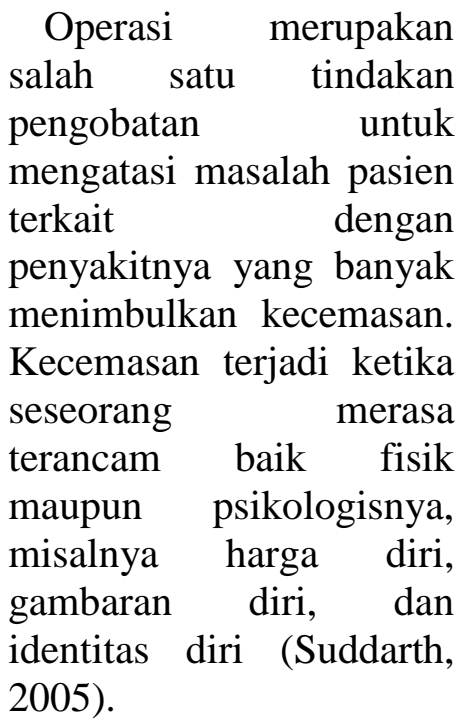

Kecemasan biasanya berhubungan dengan segala macam prosedur asing yang harus dijalani pasien dan juga ancaman terhadap keselamatan jiwa akibat prosedur pembedahan dan tindakan pembiusan. Hospitalisasi dan rangkaian prosedur tindakan sebelum operasi dilakukan juga dapat menyebabkan distress akut dan meningkatkan kecemasan pada pasien (Maranets \& Kain 1999). Menurut Jonston (1980), mengatakan bahwa pasien yang akan menjalani tindakan operasi dapat mengalami kecemasan luar biasa selama berharihari sebelum menjalani operasi dan merasa khawatir, tidak hanya mengenai yang akan terjadi sesudah itu dan efek pada keluarganya, berbagai kemungkinan buruk bisa saja terjadi yang akan membahayakan pasien, pasien yang mengalami kecemasan menunjukkan gejela mudah tersinggung, susah tidur, gelisah, lesu, mudah menangis dan tidur tidak nyenyak. Masalah ini yang harus ditanggapi oleh perawat, jika kekhawatiran tidak dikomunikasikan maka akan menganggu hubungan perawat dengan pasien serta akan dapat meningkatkan kecemasan pasien.

Kecemasan pada pasien sebelum dilakukan tindakan operasi juga bisa disebabkan karena kurang informasi tentang prosedur tindakan dan komunikasi antara 
perawat dengan pasien yang kurang efektif.

Penelitian yang dilakukan oleh Makmuri (2007) fenomena yang ada di Rumah Sakit Zahirah Jakarta Selatan tentang tingkat kecemasan pre operasi menunjukkan bahwa dari 40 orang respoden terdapat 16 orang yang memiliki tingkat kecemasan dalam kategori sedang, 15 orang dalam kategori ringan dan 7 orang dalam kategori berat serta yang tidak mengalami kecemasan sebanyak 2 orang.

Salah satu faktor penyebab terjadinya kecemasan yaitu adanya masalah fisik yang pada umumnya individu menderita suatu penyakit, dan menurut dokter harus dilakukan operasi. Fase pre operasi dari peran keperawatan dimulai ketika keputusan untuk intervensi bedah dibuat dan berakhir ketika pasien dikirim ke ruang operasi, tindakan atau pembedahan merupakan pengalaman yang sulit bagi hampir semua pasien, berbagai kemungkinan buruk bisa saja terjadi yang akan membahayakan bagi pasien, maka seringkali pasien dan keluarganya menunjukkan sikap yang agak berlebihan dengan kecemasan yang dialami. Wienman dan Jonston (1988), menyatakan bahwa pasien dalam keadaan cemas, lebih cendrung mengalami sensasi jasmaniah dan tanda-tanda terancam, kecemasan bila berlanjut dapat mempengaruhi reaksi fisik yang meliputi palpitasi, keringat dingin pada telapak tangan, tekanan arah meningkat, respirasi meningkat, sedangkan reaksi psikologis meliputi perasaan tidak enak, gugup, tegang dan mudah kaget.

Ketika menjalani tahap pre operasi, semua pasien baik operasi Elektif maupun pasien Cyto menunggu jam operasi diruang tunggu dalam waktu yang bersamaan. Dalam ruangan tersebut 
perawat dan dokter melakukan persiapan operasi untuk semua type pasien.

Ruang persiapan juga merupakan jalur antara pasien pre operasi dengan post operasi yang akan masuk ke Recovery Room, hal ini menimbulkan gambaran yang menakutkan bagi pasien yang belum pernah dioperasi. Dampak yang mungkin muncul bila kecemasan pasien pre operasi tidak segera ditangani, yang pertama pasien dengan tingkat kecemasan tinggi tidak akan mampu berkonsentrasi dan memahami kejadian buruk selama perawatan dan prosedur. Ke dua, pasien yang akan dilakukan tindakan operasi seringkali mengalami kecemasan sebagai akibat dari ketakutan pada sesuatu yang tidak diketahui dan antisipasi pada sesuatu yang tidak dikenal dan prosedurprosedur yang mungkin menyakitkan bahkan menyebabkan kecacatan atau kematian (WilsonBarnet, 2011). Ke tiga pasien akan merasa tidak nyaman dengan pembedahan jika pasien tidak mengetahui momen yang dihadapi pada saat hari pembedahan tiba. Ke empat, Apabila pasien tidak mencapai harapan yang realistik terhadap nyeri dan mengetahui cara mengatasinya, rasa cemas akan jauh meningkat.

Dalam usaha-usaha untuk mengatasi masalah kecemasan yang terjadi, individu dapat mengatasi kecemasan dengan menggerakkan sumber coping di lingkungan yang didapat dari perawat. Untuk dapat meningkatkan

kepercayaan diri pasien dalam menghadapi suatu tindakan operasi, maka salah satu cara yang harus dilakukan adalah hubungan komunikasi terapeutik perawat dengan pasien perlu dibangun agar pasien dapat memilih alternatif coping yang 
positif bagi dirinya. Sumber coping tersebut bisa didapat dari perawat sebelum akan dilakukan tindakan operasi dengan mengadakan pre interaksi yang merupakan masa persiapan sebelum berhubungan dan berkomunikasi dengan klien, perkenalan dengan memulai kegiatan dimana perawat bertemu pertama kali dengan klien. Setelah itu berorientasi dengan cara menggali keluhan yang dirasakan oleh klien, mengimplementasikan rencana keperawatan yang telah dibuat pada tahap orientasi, selanjutnya tahap terminasi, perawat mengakhiri interaksinya dengan klien ( Nasir dkk, 2009).

\section{Metode}

mengelitian

Eksperimen

ini

pendekatan One group PrePost Test Desaign. Penelitian One group Pre-Post Test Desaign adalah suatu penelitian yang dilakukan untuk mengungkapkan hubungan sebab akibat dengan cara melibatkan satu kelompok subyek dengan jumlah 1025 pasien dan ratarata pasien yang operasi setiap bulannya sebanyak 113 pasien. Sampel yang digunakan dalam penelitian ini adalah semua pasien yang akan dilakukan tindakan operasi di ruang mawar/Bedah RSUD dr. Abdoer Rahem Kabupaten Situbondo. Adapun kriteria dari sampel sangat membantu peneliti untuk mengurangi bias hasil penelitian, khususnya jika terhadap variabel (kontrol/pemicu) yang ternyata mempunyai pengaruh terhadap variabel yang kita teliti

\section{Hasil Penelitian}

1. Data Umum

a. Karakteristik Resonden berdasarkan Jenis Kelamin

Tabel 1 Distribusi berdasarkan jenis kelamin

\begin{tabular}{cccc}
\hline No & $\begin{array}{c}\text { Jenis } \\
\text { Kelamin }\end{array}$ & F & $\%$ \\
\hline 1 & Laki-laki & 11 & 39,28 \\
2 & Perempuan & 17 & 60,72 \\
\hline & Total & $\mathbf{2 8}$ & $\mathbf{1 0 0}$ \\
\hline
\end{tabular}

Berdasarkan hasil penelitian pada tabel 1 di atas, didapatkan sebagian besar responden 
dengan jenis kelamin perempuan yaitu 17 responden $(60,72 \%)$.

b. Karakteristik responden berdasarkan usia

Tabel 2

Distribusi

berdasarkan usia

\begin{tabular}{cccc}
\hline No & Usia & F & $\%$ \\
\hline 1 & $20-25$ & 8 & 28,57 \\
2 & $26-35$ & 9 & 32,14 \\
3 & $36-45$ & 11 & 39,29 \\
\hline & Total & $\mathbf{2 8}$ & $\mathbf{1 0 0}$
\end{tabular}

Berdasarkan hasil penelitian pada tabel 2, didapatkan sebagian besar responden berusia 36-45 yaitu 11 responden $(39,29 \%)$.

c. Karakteristik responden berdasarkan tingkat pendidikan

Tabel 3 Distribusi berdasarkan tingkat pendidikan

\begin{tabular}{cccc}
\hline No & $\begin{array}{c}\text { Tingkat } \\
\text { Pendidikan }\end{array}$ & F & $\%$ \\
\hline 1 & SD & 4 & 14,28 \\
2 & SMP & 14 & 50 \\
3 & SMA & 6 & 21,44 \\
4 & Perguruan & 4 & 14,28 \\
& Tinggi & & \\
\hline & Total & $\mathbf{2 8}$ & $\mathbf{1 0 0}$ \\
\hline
\end{tabular}

Berdasarkan hasil penelitian pada table 3 di atas, mayoritas responden berpendidikan SMP yaitu 14 responden (50\%).

d. Karakteristik responden berdasarkan pekerjaan

Tabel 4 Distribusi berdasarkan pekerjaan

\begin{tabular}{llll}
\hline No & Pekerjaan & F & $\%$ \\
\hline
\end{tabular}

\begin{tabular}{cccc}
\hline 1 & Tidak & 4 & 14,28 \\
2 & bekerja & & Swasta \\
2 & 18 & 64,28 \\
3 & Wiraswasta & 4 & 14,28 \\
4 & PNS & 2 & 7,16 \\
\hline & Total & $\mathbf{2 8}$ & $\mathbf{1 0 0}$ \\
\hline
\end{tabular}

Berdasarkan hasil penelitian pada tabel 4 di atas, didapatkan sebagian besar responden bekerja swasta sebanyak 18 responden $(64,28 \%)$.

\section{Data Khusus}

a. Karakteristik responden berdasarkan tingkat kecemasan pasien pre operasi sebelum dilakukan komunikasi terapeutik.

Tabel 5 Distribusi berdasarkan tingkat kecemasan pasien pre operasi sebelum dilakukan komunikasi terapeutik.

\begin{tabular}{|c|c|c|c|}
\hline No & $\begin{array}{c}\text { Tingkat } \\
\text { kecemasan }\end{array}$ & $\mathrm{F}$ & $\%$ \\
\hline 1 & Cemas ringan & 0 & 0 \\
\hline 2 & Cemas sedang & 7 & 25 \\
\hline 3 & Cemas berat & 13 & 46,43 \\
\hline 4 & Panik & 8 & 28,57 \\
\hline & Total & 28 & 100 \\
\hline \multicolumn{4}{|c|}{$\begin{array}{l}\text { Berdasarkan data yang } \\
\text { diperoleh pada tabel } 5 \text { di atas, } \\
\text { didapatkan sebagian besar } \\
\text { responden mengalami cemas } \\
\text { berat sebanyak } 13 \text { responden } \\
(46,43 \%) .\end{array}$} \\
\hline
\end{tabular}




\section{Sulastri: Komunikasi Terapeutik}

b. Karakteristik berdasarkan tingkat kecemasan pasien pre operasi setelah dilakukan komunikasi terapeutik.

Tabel 6 Distribusi berdasarkan tingkat kecemasan pasien pre operasi setelah dilakukan komunikasi terapeutik

\begin{tabular}{|c|c|c|}
\hline No & $\begin{array}{c}\text { Tingkat } \\
\text { kecemasan }\end{array}$ & $\%$ \\
\hline 1 & $\begin{array}{l}\text { Cemas } \\
\text { ringan }\end{array}$ & 50 \\
\hline 2 & $\begin{array}{l}\text { Cemas } \\
\text { sedang }\end{array}$ & 1242,82 \\
\hline 3 & $\begin{array}{c}\text { Cemas } \\
\text { berat }\end{array}$ & 10,71 \\
\hline \multirow[t]{2}{*}{4} & Panik & 3,57 \\
\hline & Total & 100 \\
\hline \multicolumn{3}{|c|}{$\begin{array}{l}\text { Berdasarkan data yang } \\
\text { diperoleh pada tabel } 6, \\
\text { didapatkan separuh dari } \\
\text { jumlah responden mengalami } \\
\text { cemas ringan sebanyak } 14 \\
\text { responden }(50 \%) \text {. }\end{array}$} \\
\hline & $\begin{array}{l}\text { Pengaruh } \\
\text { terapeutik } \\
\text { terhadap } \\
\text { kecemasan } \\
\text { pre operasi. }\end{array}$ & $\begin{array}{r}\text { komunikasi } \\
\text { perawat } \\
\text { tingkat } \\
\text { pada pasien }\end{array}$ \\
\hline
\end{tabular}

Tabel 7 Distribusi berdasarkan tingkat kecemasan pasien pre operasi

\begin{tabular}{|c|c|c|c|c|c|}
\hline \multirow{2}{*}{ No } & \multirow{2}{*}{$\begin{array}{c}\text { Tingkat } \\
\text { Kecemasan }\end{array}$} & \multicolumn{2}{|c|}{$\begin{array}{c}\text { Pre } \\
\text { treatment }\end{array}$} & \multicolumn{2}{|c|}{$\begin{array}{c}\text { Post } \\
\text { treatment }\end{array}$} \\
\hline & & $\mathrm{F}$ & $\%$ & $\mathrm{~F}$ & $\%$ \\
\hline 1 & Cemas ringan & 0 & 0 & $\begin{array}{l}1 \\
4\end{array}$ & 50 \\
\hline 2 & $\begin{array}{l}\text { Cemas } \\
\text { sedang }\end{array}$ & 7 & 25 & $\begin{array}{l}1 \\
2\end{array}$ & 42,82 \\
\hline 3 & Cemas berat & 13 & $\begin{array}{l}46 \\
43\end{array}$ & 3 & 10,71 \\
\hline 4 & Panik & 8 & $\begin{array}{l}28 \\
57\end{array}$ & 1 & 3,57 \\
\hline & Total & 28 & $\begin{array}{c}10 \\
0\end{array}$ & 8 & 100 \\
\hline
\end{tabular}

Berdasarkan hasil penelitian dari data di atas didapatkan bahwa sebelum dilakukan komunikasi terapeutik, sebagian besar responden yang mengalami cemas berat sebanyak 13 responden (46,43\%), dan setelah dilakukan komunikasi terapeutik sebagian besar responden mengalami cemas ringan 14 responden (50\%). Data dari tabel nilai interval yang terlampir menunjukkan bahwa kecemasan setiap responden mengalami penurunan

\section{Pembahasan}

1. Tingkat kecemasan pasien pre operasi setelah 
Sulastri: Komunikasi Terapeutik

\begin{tabular}{|c|c|}
\hline \multicolumn{2}{|l|}{ dilak } \\
\hline terapeutik. Pada tabel 5 & pengetahuan \\
\hline enunjukkan & keterampilan untuk da \\
\hline bagian besar kecemasan & membantu \\
\hline sponden adalah & mencapai \\
\hline sebanyak & menghad \\
\hline sponden $\quad(50 \%)$ & lingkungan yang baru. \\
\hline ponden yang mengalami & Intervensi \\
\hline mas sedang sebanyak 12 & dilakukan untuk menga \\
\hline$(42,82 \%)$ & kecemasan menurut (Is \\
\hline dangkan responden yang & adalah \\
\hline cemasannnya & menggunakan \\
\hline banyak 3 responden & kognitif dan penyulu \\
\hline $0,71 \%$ ) dan responden & manajemen \\
\hline ang panik sebanyak 1 & menggunakan \\
\hline sponen $(3,57 \%)$. & relaksasi, \\
\hline ozier dan Oliveri (1991) & strategi \\
\hline engatakan bahwa tingkat & mendorong \\
\hline manusia & perasaan, mendorong $\mathrm{kl}$ \\
\hline pengaruhi oleh stimulus & aktivitas \\
\hline ternal dan eksternal yang & mengurangi \\
\hline hadapi individu dan & lingkungan, \\
\hline nembutuhkan & tugas untuk latihan ya \\
\hline erilaku terus menerus. & terstruktur, \\
\hline roses adaptasi sering & disampaikan \\
\hline enstimulasi & menggunakan komunik \\
\hline mendapatkan & terapeutik \\
\hline dari sumber- & memotivasi pasien supa \\
\hline dilingkungan & kooperatif \\
\hline mana dia berada. perawat & melaksananakan \\
\hline erupakan sumber daya & kesemuanya itu. \\
\hline tersedia & Tingkat kecemasan sec \\
\hline gkungan rumah & dan berat menimbulkan \\
\hline
\end{tabular}


jenis mekanisme koping, yaitu dimana yang pertama merupakan reaksi yang berorientasi pada tugas, serta upaya yang didasari dan berorientasi pada tindakan untuk memenuhi secara realistik tuntutan situasi stress dan frustasi dari sesuatu yang terjadi, yakni perilaku menyerang, digunakan untuk mengubah atau mengatasi hambatan pemenuhan kebutuhan. Perilaku menarik diri, digunakan baik secara fisik maupun psikologik untuk memindahkan seseorang dari sumber stress. Perilaku kompromi digunakan untuk mengubah cara seseorang mengoperasikan, mengganti tujuan atau mengorbankan aspek kebutuhan personal seseorang. Ke dua adalah mekanisme pertahanan ego, dapat membantu mengatasi kecemasan ringan sampai sedang. Tetapi jika berlangsung pada tingkat tidak sadar dan melibatkan penipuan diri dan distoersi realitas, maka mekanisme ini merupakan respon maladaptive terhadap stress.

Dari hasil data pada tabel 6 diketahui bahwa rendahnya tingkat kecemasan pasien pre operasi ini disebabkan oleh beberapa hal diantaranya kerana pasien umumnya merasa pasrah terhadap prosedur medis yang dihadapinya, pasien dengan penyakit kronis yang akan melalui prosedur pembedahan merasa operasi adalah hal yang wajar, selain itu juga aspek spiritual pasien pre operasi meningkat sehingga lebih tenang menjalani operasi dan menganggap operasi sebagai cara terbaik dan pasien yakin kepada Tuhan. Seseorang dapat mengatasi stress dan kecemasan dengan menggerakkan sumbersumber koping yang ada di 
lingkungan yang ada sebagai modal ekonomik, kemampuan

menyelesaikan masalah dengan mencurahkannya pada perawat yang merupakan sebagai sumber daya yang tersedia di lingkungan rumah sakit, dukungan sosial dan keyakinan budaya. Hal ini yang dapat membantu seseorang

mengintegrasikan

pengalaman yang

menimbulkan stress dan mengadopsi strategi koping yang berhasil.

Dari hasil pembahasan di atas dapat disimpulkan bahwa tingkat kecemasan pasien pre operasi di Ruang Bedah RSUD dr. Abdoer Rahem Kabupaten Situbondo berada pada tingkat cemas yang rendah (ringan-sedang)

disebabkan karena operasi yang dilakukan adalah operasi yang elektif (direncanakan) dan dapat juga karena kecemasan yang tidak teridentifikasi sebelumnya. Hal ini sesuai dengan pendapat Atkinson (1992) yang mengatakan bahwa semua pasien pre operasi umumnya mengalami kecemasan walaupun tidak diungkapkan secara verbal dan kemampuan pasien meningkat dalam menghadapi situasi krisis yang akan terjadi.

2. Pengaruh komunikasi terapeutik perawat terhadap tingkat kecemasan pada pasien pre operasi.

Berdasarkan data dari hasil penelitian, didapatkan bahwa terdapat pengaruh komunikasi terapeutik perawat terhadap penurunan tingkat kecemasan pada pasien pre operasi. Pada tabel 5 menunjukkan bahwa sebelum dilakukan komunikasi terapeutik jumlah responden yang mengalami cemas ringan 0 (0\%), dan yang mengalami cemas sedang sebanyak 7 
Sulastri: Komunikasi Terapeutik

responden

$(25 \%)$,

sedangkan sebagian besar

responden yang mengalami

cemas berat sebanyak 13 responden yaitu $(46,43 \%)$, dan panik sebanyak 8 responden

$(28,57 \%)$.

Setelah

dilakukan

komunikasi

terapeutik

terdapat perubahan tingkat kecemasan yaitu sebagian besar responden

mengalami cemas ringan 14 responden $(50 \%)$, yang mengalami cemas sedang sebanyak 12 responden (42,82\%), cemas berat berjumlah 3 responden (10,71\%), sedangkan jumlah responden yang mengalami panik sangat minimal yaitu 1 responden $(3,57 \%)$.

Dari perhitungan hasil penelitian dari 28 responden tentang tingkat kecemasan sebelum dan sesudah perlakuan komunikasi terapeutik dengan menggunakan SPSS uji statistik T-Test, didapatkan hasil signifikansi bahwa $\rho<\alpha$ yaitu $0,000<0,05$.

Sehingga H1 diterima, yang artinya terdapat pengaruh komunikasi terapeutik yang signifikan pada tingkat kecemasan pasien pre operasi di Ruang Bedah RSUD dr. Abdoer Rahem Kabupaten Situbondo.

Komunikasi terapeutik didefinisikan sebagai komunikasi yang direncanakan secara sadar, bertujuan dan kegiatan dipusatkan untuk kesembuhan pasien (Uripni dkk, 2003). Taylor (1997) menyatakan bahwa pembedahan (operasi) adalah krisis dalam kehidupan yang menyebabkan kecemasan. Kecemasan merupakan pengalaman individu yang bersifat emosional dan subyektif yang tidak mampu diobservasikan secara langsung serta merupakan suatu keadaan emosi tanpa subyek yang spesifik yang dialami dan dikomunikasikan secara 
Sulastri: Komunikasi Terapeutik

interpersonal, biasanya kecemasan timbul tanpa diketahui dan akibat pengalaman yang baru (Sundari, 2005). Perawat dapat mengurangi dan memperbaiki kecemasan pasien dengan tindakan keperawatan yang difokuskan pada komunikasi terapeutik dan pendidikan kesehatan pasien serta keluarganya. Selama proses komunikasi berlangsung pasien umumnya mengekspresikan kecemasan dan perasaannya tentang operasi dan penyakit yang dialaminya. Hal ini sesuai dengan pendapat Torrence dan Serginson (1997) yang mengatakan bahwa pasien pre operasi membutuhkan waktu tertentu untuk mengekspresikan kecemasannya dan menanyakan hal yang penting yang terkait dengan operasi. Interaksi antara perawat dan pasien dapat meningkatkan mekanisme koping dan memberi dukungan emosional kepada pasien yang mengalami kecemasan dan rasa takut. Selain itu adanya komunikasi yang dilakukan perawat (peneliti) dengan menginformasikan

prosedur pembedahan (persiapan pasien, obatobat pre medikasi, jenis pembedahan, anastesi, latihan post operasi) dan hal-hal terkait dengan proses pembedahan juga hal di luar proses pembedahan mampu memberikan efek positif terhadap penurunan tingkat kecemasan pasien.

Dan dilihat dari tebel nilai interval yang terlampir dapat diketahui bahwa setiap responden mengalami penurunan tingkat kecemasan, meskipun masih ada responden yang penurunan tidak terlalu banyak, tetapi tetap mengalami penurunan tingkat 
kecemasan, ini

dikarenakan oleh seseorang yang berada pada lingkungan asing ternyata masih memberikan rasa kecemasan dibandingkan bila ada di lingkungan yang biasanya, Hal ini berarti bahwa komunikasi terapeutik memberikan pengaruh terhadap kecemasan pasien. Dari hasil perbandingan respon kecemasan sebelum dan sesudah komunikasi yang dialami oleh responden, peneliti dapat mengambil kesimpulan bahwa tindakan perawat dapat membantu mengurangi atau menurunkan kecemasan pasien dengan memastikan pasien memahami proses pembedahan dan menentramkan perasaan klien. Respon kecemasan yang dapat diturunkan melalui proses komunikasi terapeutik adalah responrespon yang terkait psikologis yaitu perasaan kecewa, perasaan tak berdaya dan perasaan tidak berharga (takut ditolak).

\section{Simpulan}

Komunikasi terapeutik perawat menjadi ujung tombak dalam pelayanan keperawatan sehingga adanya kontribusi yang sangat signifikan terhadap tingkat kecemasan pada pasien pre operasi di Ruang Bedah RSUD dr. Abdoer Rahem Kabupaten Situbondo.

\section{Daftar Pustaka}

Arikunto, S. (2006), Prosedur Penelitian Suatu Pendekatan Prektik. Jakarta: Rineka Cipta. Andaners. (2009). Tingkat Kecemasan Pasien Pre Operatif diruang Bedah Pria.

http://spesialisbedah.co m/2008/12/persiapanoperasi/. Diakses pada tanggal 3 maret 2011.

Hardjito and Freudman. (2001). Kecemasan Pada Manusia. http://pmkes.blogspot.c om/2010/04/kecemasanpada-manusia.html. 
Sulastri: Komunikasi Terapeutik

Diakses pada 14 April 2010

Hidayat, A, A. (2003), Riset Keperawatan dan Teknik Penulisan Ilmiah. Jakarta: Salemba Medika.

A, A. (2009), Metode Penelitian Kebidanan dan Teknik Analisa Data. Jakarta: Rineka Cipta.

Mitchell. (2008). A Web Based Short Messasing Service System, Upaya Menurunkan

Kecemasan Yang

Dialami Pasien Dan Keluarganya Yang Sedang Menjalani Operasi. Diakses pada 1 juli 2009.

Nasir, A. (2009). Komunikasi Dalam Keperawatan teori dan Aplikasi, Jakarta, Salemba Medika.

Notoatmodjo, S. (2005), Metodelogi Penelitian Kesehatan. Jakarta: Rineka Cipta.

Nursalam. (2008), Konsep dan Penerapan Metodelogi Penelitian Ilmu Keperawatan : Pedoman Skripsi, Tesis dan Instrumen
Penelitian. Jakarta: Salemba Medika.

Rekam Medik RSUD dr. Abdoer Rahem Situbondo (2011). Sheldon, L, K. (2009). Komunikasi Untuk Keperawatan Berbicara Dengan Pasien. Jakarta. Erlangga.

Smeltzer, Suzanne C. and Brenda G. Bare, (2005). Buku Ajar Keperawatan Medikal Bedah Brunner Suddarth, EGC, Jakarta. Smeltzer, Suzanne C. and Brenda G. Bare. (2001). Buku Ajar Keperawatan Medikal Bedah Brunner Suddarth. Jakarta. EGC. Sugyono. (2009), Metode Penelitian Kuantitatif Kualitatif Dan R\&D, Bandung, Alfabeta.

Sundari. (2005). Dalam Ocad Abdullah: Tingkat Kecemasan Klien Fraktur Tentang Tindakan Per Operatif. Edisi 2005. Jombang. AKPER Bahrul "ulum Jombang.

Uripni, christina lia. (2003). Komunikasi Kebidanan. Editor Monica Ester. Jakarta. ECG. 
Sulastri: Komunikasi Terapeutik

$\begin{array}{cr}\text { Wilson-Barnet } & (2011), \\ \text { pengaruh } & \text { komunikasi } \\ \text { terapeutik } & \text { terhadap } \\ \text { tingkat } & \text { kecemasan } \\ \text { pasien } & \text { pre. } \\ \text { operasi.http://grahacend } \\ \text { ikia.wordpress.com/201 } \\ \text { 1/03/26/pengaruh- } \\ \text { komunikasi-terapeutik- } \\ \text { terhadap-tingkat- } \\ \text { kecemasan-pasien-pre- } \\ \text { opeatif-di-rumah-sakit- } \\ \text { xx/. diakses pada 26 } \\ \text { maret 2011. }\end{array}$

